\title{
Career Adaptability: The Influence of Readiness and Adaptation Success in the Education Context: a Literature Review
}

\author{
Wiwik Sulistiani \\ Universitas Hang Tuah \\ Seger Handoyo \\ Faculty of Psychology, AirlanggaUniversity \\ wiecha01@gmail.com
}

\begin{abstract}
Late adolescence or by the age of 20, adolescence enter during the transition to early adulthood. One of the developmental tasks experienced by individuals during this period is the establishment of career identities. In an effort to meet the establishment of identity is required career adaptability. Career adaptability is a psychosocial construct that shows individual resources to overcome and anticipate tasks, transitions, traumas in job roles, to some degree large or small, that alter the social integration of individuals. Based on the theory of career construction, the authors conducted a literature review of 16 journals on empirical studies of factors that cause career adaptability and its influence in the educational context. The results show that career adaptability is associated with multiple demographic factors (age, gender), career adaptivity (conscientiousness, positive emotional disposition, belief in ability, future orientation, hope, optimism, adversity quotient and self-regulation), and external factors (social support parents, family support, school environment). The success of career adaptability in the educational context is associated with life satisfaction, sense of power, career management, career certainty, classroom involvement, academic achievement and academic fatigue. The main findings are career adaptability influenced by demographic factors, career readiness: internal factors (personality) and individual external factors. Career adaptability leads to positive and negative effects on the individual in the educational context.
\end{abstract}

Keywords: Career adaptability, adaptivity, university, school

\section{INTRODUCTION}

The development stages of individuals in late adolescence to adulthood to at least the age of the mid$20 \mathrm{~s}$, it has been proposed that at this stage is a new and different potential developmental period, called emerging adulthood or between adolescence and adolescence (Arnett, 2003). At this stage, the individual has a developmental task that is making provision related to commitment in life. These commitments, for example, establish romantic relationships, make career choices, and so on. At this stage, the individual must fulfill the task of psychological development that is to establish the identity of a stable and decent individual as to direct and maintain this commitment (Schwartz, Côté, \& Arnett, 2005).

A variety of issues arise in this transitional period Individuals experience a change in their relationship with family and friends, and. Individuals experience a change in their relationship with family and friends (Kerr, Johnson, Gans, \& Krumrine, 2004), experiencing obstacles in the face of realizing career goals (Hurtado, Han, Sa, Cabrera, \& Cerna, 2007), make career decisions (Kerr et al., 2004), lack of career preparation can have a direct and indirect effect on vocational issues (Skorikov, 2007). Students are in a phase of life where they should think about career choices and how to achieve their career goals (Chong \& Leong, 2017). Among the career preparation components, career confusion has received the greatest attention (Creed, Prideaux, \& Patton, 2005). Years of high school and university, when students have to make decisions about work and further education, are essential in regard to career decision-making processes and adaptability (Buyukgoze-kavas, 2014).
Career issues have become an important issue in education today, as individuals need to identify careerrelated identities immediately. Various problems arise for example is feeling confused in choosing the school majors, choosing the majors because there are friends, parents orders, has chosen the department was not suitable, and feeling uncomfortable with the majors that have been chosen. Recent studies of career adaptability in educational contexts relating to school-to-work transition are widely discussed.

\section{Theory of career adaptability}

Theory of career construction is not focused on people or the environment known as P-E symbol or in other word to build a career is a psychosocial activity, which synthesize themselves and society, Savickas (2005) as the progress of vocational development theory Super (1957), career construction theories focus primarily on how individuals use their vocational personalities to adjust the sequence of job changes (Savickas, 1997, 2005).

Adaptability is 'quality can change, without great difficulty, to adapt new or changed circumstances' (Savickas, 2007). Career adaptability is one psychosocial constellation that shows individual resources to address current tasks and anticipate the development, transition of work, and job traumas, which is to some degree is large or small, and alter the social integration of individuals (Savickas, 2007). Career adaptability can be explored in various forms depending on the domain. In the career development domain, career adaptability is highly relevant. It shows psychosocial constructs that reflect individual resources to overcome challenges, such as developmental tasks 
and work transitions, which are an inevitable part of life(Savickas \& Porfeli, 2012).

Career adaptability also includes the idea of a personal agency, however, because psychosocial offers a different perspective to look at personal capacity and should be highly relevant in understanding construction and career management. First of all, it refers to aspects of unexamined career development that are only partially reflected from other similar constructs. Second, the components are well integrated both in terms of temporal focus which is an important issue in career choice. Third, it emphasizes personal initiative and is responsible for one's career construction, which is in accordance with the reality of the modern world, as well as the latest theoretical approach to career development. Finally, derived from the concept of career maturity, it provides a more up to date approach to career development skills (Urbanaviciute, Kairys, Pociute, \& Liniauskaite, 2014).

Several career adaptation abilities have been differentiated within the framework of career construction, such as concern, control, curiosity, confidence and commitment (Savickas et al., 2009). Theoretically, each serves as a basis for developing individual strategies that facilitate in handling various job tasks or acting flexibly (Urbanaviciute et al., 2014). Career adaptation resources are the strength or capacity of self-regulation that a person can take to solve unfamiliar, complex, and unclear problems presented by vocational or job assignments, job transitions, and job traumas. These resources are not the core of the individuals, they are located as the intersection between the individual and the environment. Career adaptation resources are modeled as multi-dimensional and hierarchical. Four dimensions of the source of career adaptability are referred to the adaptation capabilities of concern, control, curiosity and confidence. Concern is a concern about the future that helps individuals to look ahead and prepare for what will happen next. Control allows individuals to be responsible for shaping themselves and the environment to meet what will happen next using self-discipline, effort, and persistence. The possible and alternative scenarios that they might form are explored when curiosity encourages one to think of oneself in different situations and roles. This experience of exploration and information-seeking activity generates aspirations and builds confidence that the person can actualize the choice to apply his or her life design. So when vocational tasks, work transitions, or work traumas occur, adaptable individuals are conceptualized as (a) being concerned with the future of vocational, (b) controlling of trying to prepare for the future of one's vocation, (c) displaying curiosity by exploring the possibility of self and scenarios of the future, and (d) strengthening self-confidence to pursue one's aspirations (Porfeli \& Savickas, 2012).

A higher level of adaptation (outcome) is expected for adaptive and adaptable individuals to engage in behavior to cope with changing conditions (adaptation). Career construction theory sees adaptability as a psychological style and adaptability as a psychosocial strategy (Savickas, 2007). Emphasis on the psychosocial dimension distinguishes career adaptability from stable individual characteristics (ie disposition). Adaptation (contrary to adaptivity) should be seen as a self-regulation capacity rather than a core personality trait. Looking from a theoretical point of view, career adaptability can be placed between constructs that reflect a personal agent or perceived ability to achieve one's life goals (Savickas \& Porfeli, 2012; Urbanaviciute et al., 2014).

Based on the model of career construction theory, people build careers using adaptive strategies that apply their personality in work roles. This adaptation is motivated and guided by the goal of bringing inner needs and external opportunities into harmony, with appropriate harmony to reinforce current activities of past preoccupations and aspirations today. Adaptation, or a good adaptation, is demonstrated by success, satisfaction, and development (Savickas \& Porfeli, 2012).

\section{Adaptivity}

Adaptivity is a component of trait in the career adaptability model (Savickas \& Porfeli, 2012; Tolentino et al., 2014) shows the nature of a flexible or volatile personality. Willingness to adapt is considered to be an increasingly stable and durable trait or a basic trend that lies at the core of the individual (Savickas, 2007; Savickas \& Porfeli, 2012). The willingness to meet career disequilibrium or transition with appropriate response in an adaptive show. Thresholds for initiating interpersonal and intrapersonal processes that guide goal-directed activity are achieved when one can no longer assimilate change and persist in routine activities. At that time, individuals need to accommodate imbalances by changing themselves, the context, or both. The accommodation needed usually encourages feelings of distress to encourage motivation and strengthen the willingness to adapt. Adaptivity is conceptualized as self-regulation tendency and operated as goal orientation learning, proactive personality, and career optimism (Tolentino et al., 2014).

\section{Successful adaptation}

People who have higher adaptation levels are more flexible and have better adaptability to cope with changing conditions. The career constructions theory suggests that career success is gained for an adaptable individual and the ability to express appropriate behavior in overcoming changing conditions. This is demonstrated by good adjustment, success and satisfaction(Savickas \& Porfeli, 2012).

\section{Research Question}

What factors influence the readiness and success of career adaptability in the educational context?

\section{METHODOLOGY}

Design review in this article refers to the systematic review of qualitative (Green, Johnson, \& Adams, 2001). This type of review literature is an integrative review. The authors present and summarize the state of a keen knowledge on a topic, agree on the agreement and disagreement within it and combine it with the context (Neuman, L, 2011). The process in this 
review goes through three stages (Galvan, 2006), ie looking for literature, review and write reviews.

\section{Literature Search}

The literature search is obtained through books, searches via electronic databases PsychINFO, ProQuest, Science Direct, Google Scholar. The search strategy is focused by using the keyword "career adaptability," career adapt-abilities ".

\section{Reviewing Literature}

This stage is the selection of articles, organize the appropriate articles, how relevant to the theme of the selected research and whether the publication is an empirical study or not. The author sets out three criteria as follows: (1) the results of empirical studies using the concept of career construction theory of Savickas; (2) research context is education (school, university, vocational school) (3). Subjects were students or person related to education. This study examines the variables that affect career adaptability and the effect of career adaptability in the educational context. At this stage there is a selection of journals whose research subject workers are not used. The authors found the journal as many as 45 journals of research on career adaptability, but only 16 journals which are based on the criteria. To explore the purpose of this article, the authors examine in depth the various empirical studies of career adaptability that explain the factors and their effects on the individual.

\section{Writing the literature review}

At this stage the authors review the briefed notes prepared and review their suitability with empirical studies and review them in detail. The first step is to critically analyze the methodological approach, strengths and weaknesses, key findings, implications and conclusions from each empirical study (Galvan 2006). Appendix 1 (Table 2) illustrates a summary of the criteria used in analyzing summary literature. The annex captures the variables studied, methodological approaches, strengths and weaknesses and summarizes the findings in the study.

Table 1.List of literature reviewed, 16 titles of research results written by the author alphabetically

\begin{tabular}{|c|c|c|c|c|}
\hline Author (Years) & Subject & Goal & Approach Methodology & Concept Theory \\
\hline $\begin{array}{l}\text { Andreas } \\
\text { Hirschi (2009) }\end{array}$ & $\begin{array}{lr}330 & \text { Swiss } \\
\text { students aged } 12 \\
\text { to } 16 \text { years. The } \\
\text { education system } \\
\text { places a strong } \\
\text { emphasis } \\
\text { vocational and } \\
\text { training. }\end{array}$ & $\begin{array}{l}\text { Examining factors } \\
\text { that affect career } \\
\text { ability and its effect } \\
\text { on the sense of power } \\
\text { and experience of life } \\
\text { satisfaction. }\end{array}$ & Longitudinal & $\begin{array}{ll}\text { 1. } & \begin{array}{l}\text { System } \\
\text { motivation theory }\end{array} \\
\text { (Ford, 1992) } \\
\text { 2. } & \begin{array}{l}\text { Career } \\
\text { adaptability } \\
\text { Savickas }\end{array}\end{array}$ \\
\hline
\end{tabular}

\section{indings}

1. Men have more goal-setting and belief in higher abilities than women

2. Better emotional tendencies and more positive social context beliefs are significant predictors of increased interpersonal adaptability capabilities over time.

3. Career adaptability affects the sense of power and life satisfaction

4. In accordance with the motivational theory of the four predictor motivation theory to achieve the estimated career adaptability that is positive emotional disposition, goal determination, ability belief, and social context trust is a significant predictor of achievement in career adaptability during 1 year of school.

5. Parental education does not affect the development of career adaptability

6. Age and gender do not affect the development of career adaptability

\begin{tabular}{|c|c|c|c|c|c|c|}
\hline $\begin{array}{l}\text { Andreas Hirschi } \\
(2010)\end{array}$ & $\begin{array}{l}262 \text { students in } \\
\text { seventh grade in } \\
\text { Switzerland (age } \\
1315 \text { years) }\end{array}$ & $\begin{array}{l}\text { assessing the extent } \\
\text { to which the } \\
\text { aspirations of a } \\
\text { teenage Swiss career } \\
\text { in seventh grade } \\
\text { reflecting the } \\
\text { structure of } \\
\text { opportunity in each } \\
\text { environment and } \\
\text { chronological age, } \\
\text { the individual level } \\
\text { of career adaptation, } \\
\text { or attending school } \\
\text { tracks will predict the } \\
\text { rate of development } \\
\text { career, aspirations in } \\
\text { terms of realism, } \\
\text { stability, and } \\
\text { coherence. }\end{array}$ & Cross-sectional study & $\begin{array}{l}\text { Career adaptability } \\
\text { theory of Savickas } \\
\text { view of contextual } \\
\text { development } \\
\text { development } \\
\text { (Vondracek } \\
\text { et al, 1983; . Vondracek } \\
\text { \& Reitzle, 1998) }\end{array}$ & 2. & $\begin{array}{l}\text { Age does not correlate } \\
\text { significantly with career } \\
\text { adaptability levels. Individual } \\
\text { involvement in career } \\
\text { preparation tasks rather than } \\
\text { chronological age, determines } \\
\text { the extent of career aspiration } \\
\text { development in adolescence. } \\
\text { The ability of career adaptation } \\
\text { is also not significantly related } \\
\text { to career aspiration variables } \\
\text { Most students who participate } \\
\text { in seventh grade have } \\
\text { aspirations about what they } \\
\text { want to do when leaving school, } \\
\text { which is already adapted to the } \\
\text { existing environmental } \\
\text { structure. }\end{array}$ \\
\hline
\end{tabular}




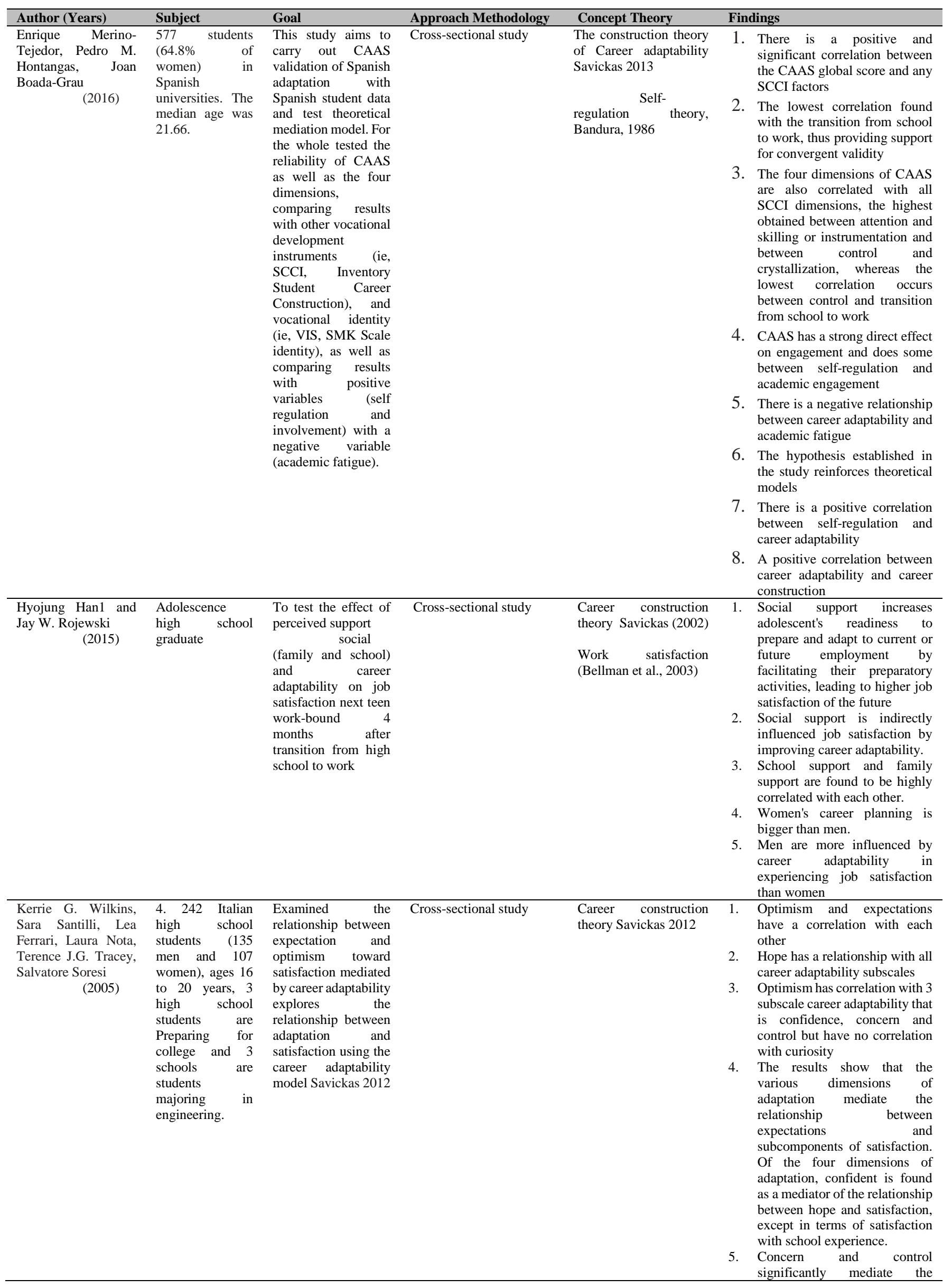




\begin{tabular}{llllll}
\hline Author (Years) & Subject & Goal & Approach Methodology & Concept Theory & Findings \\
\hline & & & rel
\end{tabular}

relationship

between

expectation and dimension of

satisfaction or optimism and

dimension of satisfaction

6. The mediation effect of the

adaptation subcomponent

occurs only through optimism

7. Optimism shows a significant direct effect on two of the 7 dimensions of satisfaction, satisfaction with current living conditions and satisfaction with relationships with family members. These results offer support for mediation capabilities of 2 dimensions of career adaptability (confident and curiosity)

\begin{tabular}{|c|c|c|c|c|c|}
\hline $\begin{array}{lr}\text { Ieva Urbanaviciute, } \\
\text { Birute } & \text { Pociute, } \\
\text { Antanas } & \text { Kairys, } \\
\text { Audrone Liniauskaite } & (2016)\end{array}$ & $\begin{array}{l}288 \text { first year } \\
\text { undergraduate } \\
\text { students } \\
\text { represent more } \\
\text { than } 20 \text { academic } \\
\text { disciplines, such } \\
\text { as tourism, } \\
\text { information } \\
\text { technology, } \\
\text { physics, social } \\
\text { sciences, or } \\
\text { language studies. }\end{array}$ & $\begin{array}{lr}\begin{array}{l}\text { Demonstrate } \\
\text { students }\end{array} \text { perceptions } \\
\text { of career barriers are } \\
\text { related to other } \\
\text { career } & \text { variables } \\
\text { concerned } & \text { upon } \\
\text { entering } & \text { higher } \\
\text { education, such as } \\
\text { academic primary } \\
\text { satisfaction rand } \\
\text { vocational identity } \\
\text { commitment. }\end{array}$ & Cross-sectional study & $\begin{array}{l}\text { Career construction } \\
\text { theory (Savickas) }\end{array}$ & $\begin{array}{l}\text { 1. Career barriers are } \\
\text { considered to be detrimental } \\
\text { to student vocational results, } \\
\text { but in cases of internal } \\
\text { barriers only } \\
\text { 2. External barriers are not } \\
\text { considered to be detrimental } \\
\text { to students' vocational results }\end{array}$ \\
\hline 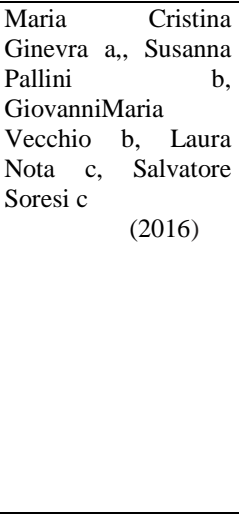 & 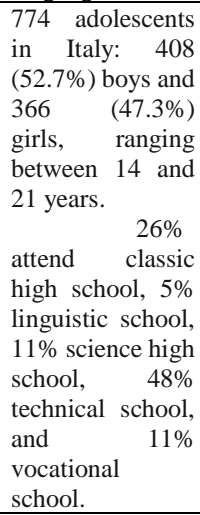 & $\begin{array}{l}\text { This study aims to } \\
\text { analyze the role of } \\
\text { mediational positive } \\
\text { attitude toward the } \\
\text { future and future } \\
\text { orientation about the } \\
\text { relationship between } \\
\text { career adaptability } \\
\text { and career certainty. }\end{array}$ & Cross-sectional study & $\begin{array}{l}\text { Career construction } \\
\text { theory Savickas (2013) }\end{array}$ & $\begin{array}{l}\text { 1. With regard to contemporary } \\
\text { socioeconomic } \\
\text { contingencies, adolescents } \\
\text { consider them able to handle } \\
\text { developmental tasks and } \\
\text { especially with changes in the } \\
\text { labor market and working } \\
\text { conditions } \\
\text { 2. A positive future and positive } \\
\text { feelings to pursue their goals } \\
\text { and desires } \\
\text { 3. Be able to imagine some } \\
\text { future scenarios. }\end{array}$ \\
\hline $\begin{array}{l}\text { Mantak Yuen, } \\
\text { Josephine Yau } \\
\qquad(2015)\end{array}$ & 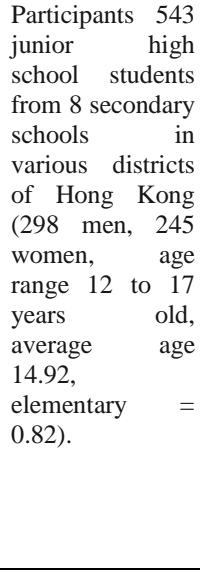 & $\begin{array}{l}\text { Determining } \\
\text { whether students } \\
\text { with better meanings } \\
\text { established in life } \\
\text { will also showcase } \\
\text { their adaptable career } \\
\text { abilities } \\
\text { not, as suggested by } \\
\begin{array}{l}\text { an existential } \\
\text { approach (firmly, } \\
\text { 2012) }\end{array}\end{array}$ & Descriptive statistics & $\begin{array}{l}\text { Career adaptability } \\
\text { (Sarvickas) }\end{array}$ & $\begin{array}{l}\text { The presence of meaning in life is } \\
\text { a predictor of career, control, } \\
\text { curiosity, and self-confidence } \\
\text { from male and female students. } \\
\text { The search for meaning in life is } \\
\text { not a predictor of a career for male } \\
\text { students but it is the linkage of } \\
\text { school that is a predictor of the } \\
\text { career of male students. As for } \\
\text { women searching for meaning in } \\
\text { life is not associated with caring or } \\
\text { career confidence but for women, } \\
\text { the relationship of career is a } \\
\text { predictor of career awareness } \\
\text { although career attention is } \\
\text { predicted with the meaning in life } \\
\text { and connectedness in school, } \\
\text { while the connectedness with } \\
\text { peers is negative. }\end{array}$ \\
\hline $\begin{array}{l}\text { Pianpian Guan a,1, } \\
\text { Alessandra } \\
\text { Capezio, 1, Simon } \\
\text { Lloyd D. Restubog,1, } \\
\text { Shari Readb, } \\
\text { Jennifer Ann } \\
\text { L. Lajomb, Min Li } \\
\text { (2016) }\end{array}$ & $\begin{array}{l}\text { 1. } 731 \text { students in } \\
\text { South China, the } \\
\text { sample consists } \\
\text { of } 63.9 \% \text { male, } \\
36.1 \% \text { female, } \\
\text { with an average } \\
\text { age of } 21-29\end{array}$ & $\begin{array}{l}\text { Test the moderate } \\
\text { role of traditionality } \\
\text { beliefs by integrating } \\
\text { career } \\
\text { adaptability and } \\
\text { cognitive evaluation, } \\
\text { developing a better } \\
\text { understanding of the } \\
\text { influence of cultural } \\
\text { variables on career }\end{array}$ & Cross sectional study & $\begin{array}{l}\text { Career construction } \\
\text { theory (Savickas, } \\
2013) \\
\text { Teori evaluasi kognitif } \\
\text { (Ryan \& Deci, 2002), }\end{array}$ & $\begin{array}{l}\text { 1. There is parental support that } \\
\text { is positively associated with } \\
\text { career adaptability } \\
\text { 2. There is parental support } \\
\text { positively related to self- } \\
\text { efficacy career decision } \\
\text { making } \\
\text { 3. The indirect effect between } \\
\text { parental support time } 1 \text { and } \\
\text { career adaptation time } 2 \\
\text { through decision-making }\end{array}$ \\
\hline
\end{tabular}




\begin{tabular}{|c|c|c|c|c|c|}
\hline Author (Years) & Subject & Goal & Approach Methodology & Concept Theory & Findings \\
\hline & & $\begin{array}{l}\text { construction } \\
\text { processes. }\end{array}$ & & & $\begin{array}{l}\text { career self-efficacy time } 1 \text { is } \\
\text { significantly stronger for } \\
\text { lower traditional beliefs than } \\
\text { high traditional beliefs } \\
\text { 4. Higher traditionality reduces } \\
\text { the effects of parental support } \\
\text { on career development and } \\
\text { self-efficacy decision } \\
\text { making, which inhibits career } \\
\text { adaptability }\end{array}$ \\
\hline $\begin{array}{lr}\text { Oana } & \text { Negru- } \\
\text { Subtirica, } & \text { Eleonora } \\
\text { Ioana Pop } & \\
& (2016)\end{array}$ & $\begin{array}{l}1,151 \text { adolescents } \\
\text { from seven } \\
\text { schools in North- } \\
\text { West Romania in } \\
\text { the age range } \\
\text { range } 13-19 \text { years } \\
(58.7 \% \text { female } \\
\text { and } 41.3 \% \text { male }) .\end{array}$ & $\begin{array}{l}\text { This study aims to } \\
\text { determine the } \\
\text { longitudinal positive } \\
\text { correlation between } \\
\text { career adaptability, } \\
\text { and investigate the } \\
\text { moderating role of } \\
\text { sociodemographic } \\
\text { variables (gender, } \\
\text { school type, youth } \\
\text { type, and age). }\end{array}$ & Longitudinal study & $\begin{array}{l}\text { Career construction } \\
\text { theory Savickas } 2012\end{array}$ & $\begin{array}{l}\text { 1. Limitations in the final stages } \\
\text { with the incorporation of } \\
\text { involvement and extinction } \\
\text { (adaptation results) } \\
\text { 2. Involvement and fatigue may } \\
\text { be process variables more } \\
\text { related to adaptation and } \\
\text { SCCI than actual results } \\
\text { variables (such as } \\
\text { satisfaction, success, and } \\
\text { stability). The research is } \\
\text { transverse and the use of } \\
\text { sample (not probability) is } \\
\text { convenient. }\end{array}$ \\
\hline $\begin{array}{l}\text { Ryan D. Duffy, } \\
\text { Richard P. Douglass, } \\
\text { Kelsey L. Autin } \\
\qquad(2015)\end{array}$ & $\begin{array}{l}\text { Participants in } \\
\text { this study were } \\
412 \text { students with } \\
\text { an average age of } \\
18.9 \text { years }\end{array}$ & $\begin{array}{l}\text { The purpose of this } \\
\text { study is to examine } \\
\text { how the four } \\
\text { components of career } \\
\text { adaptation - } \\
\text { attention, control, } \\
\text { curiosity, and trust - a } \\
\text { relationship with } \\
\text { academic satisfaction } \\
\text { among students and } \\
\text { the extent to which } \\
\text { this relationship is } \\
\text { mediated by hard } \\
\text { work and CDSE }\end{array}$ & Cross-sectional study & $\begin{array}{l}\text { Career construction } \\
\text { theory (Savickas) }\end{array}$ & $\begin{array}{l}\text { 1. } \\
\text { Each dimension of career } \\
\text { adaptation is significantly } \\
\text { correlated with academic } \\
\text { satisfaction } \\
\text { 2. Each career adaptation } \\
\text { dimension with two mediator } \\
\text { variables (work volution with } \\
\text { CDSE) and two mediator } \\
\text { variables significantly } \\
\text { correlated with academic } \\
\text { satisfaction }\end{array}$ \\
\hline \begin{tabular}{l}
\multicolumn{2}{c}{ Sara } \\
Santilli1, Jenny \\
Marcionetti2,3, She \\
kina Rochat2, \\
Je 'ro ^me Rossier2, \\
and Laura Nota \\
(2017)
\end{tabular} & \begin{tabular}{l}
\multicolumn{1}{c}{ The } \\
sample consisted \\
of 1,259 \\
adolescents, 618 \\
men and 651 \\
women
\end{tabular} & $\begin{array}{l}\text { analyze } \\
\text { the relationship } \\
\text { between career } \\
\begin{array}{l}\text { adaptation, } \\
\text { expectations, and } \\
\text { optimism on } \\
\text { satisfaction live }\end{array}\end{array}$ & & & $\begin{array}{l}\text { The } \\
\text { teenager has career } \\
\text { adaptability and a slightly } \\
\text { higher future orientation. } \\
\text { These results } \\
\text { confirm the } \\
\text { importance of differentiating } \\
\text { countries when model testing }\end{array}$ \\
\hline & & $\begin{array}{l}\text { Swiss and Italian } \\
\text { youth. }\end{array}$ & & & $\begin{array}{l}\text { connects the overall } \\
\text { adaptation of a career, future } \\
\text { orientation, and satisfaction } \\
\text { with life. }\end{array}$ \\
\hline
\end{tabular}

\begin{tabular}{|c|c|c|c|c|c|c|c|}
\hline $\begin{array}{l}\text { Simon Larose } \\
\text {, Catherine F. Ratelle } \\
\text { Frédéric Guay, } \\
\text { Caroline } \\
\text { Senécal \& Marylou } \\
\text { Harvey }\end{array}$ & $\begin{array}{l}\text { late adolescence } \\
\text { late } \\
(216 \text { women, } 195 \\
\text { men) college } \\
\text { studies. }\end{array}$ & $\begin{array}{l}\text { This } \\
\text { study aims to better } \\
\text { understand the } \\
\text { personal } \\
\text { determinants that } \\
\text { attract youth in } \\
\text { science, } \\
\text { their level of } \\
\text { decisiveness with } \\
\text { regard to future } \\
\text { careers in } \mathrm{S} \& \mathrm{~T} \text {, and } \\
\text { their achievements } \\
\text { and diligence in S \& } \\
\mathrm{T} \text { programs in } \\
\text { college. }\end{array}$ & $\begin{array}{l}\text { Cross- } \\
\text { sectional Study }\end{array}$ & $\begin{array}{l}\text { Cognitive } \\
\text { Bandura }\end{array}$ & $\begin{array}{l}\text { Social } \\
\text { theory }\end{array}$ & 1. & $\begin{array}{l}\text { One-way analysis of variance } \\
\text { shows no significant } \\
\text { difference between } \\
\text { three track } \\
\text { groups in terms of high } \\
\text { school academic } \\
\text { achievement, } \\
\text { These findings suggest that, } \\
\text { for most students, the college } \\
\text { transition is a positive } \\
\text { experience despite the well- } \\
\text { known developmental } \\
\text { heterogeneity in self-efficacy } \\
\text { beliefs. } \\
\text { The gender and choice of } \\
\text { programs slowed the } \\
\text { student's path of self-efficacy } \\
\text { science conviction over the } \\
\text { college transition. }\end{array}$ \\
\hline
\end{tabular}




\begin{tabular}{|c|c|c|c|c|}
\hline Author (Years) & Subject & Goal & Approach Methodology & Concept Theory \\
\hline $\begin{array}{c}\text { SinHui Chong and } \\
\text { Frederick T. L. Leong } \\
(2016)\end{array}$ & $\begin{array}{l}307 \text { students } \\
\text { with work } \\
\text { experience }\end{array}$ & $\begin{array}{l}\text { View the relationship } \\
\text { between individual } \\
\text { characters } \\
\text { (awareness, } \\
\text { cognitive flexibility } \\
\text { and workplace } \\
\text { exploration), career } \\
\text { adaptability and } \\
\text { management } \\
\text { strategies }\end{array}$ & Cross-sectional study & $\begin{array}{l}\text { Career construction } \\
\text { theory Savickas } 2012\end{array}$ \\
\hline
\end{tabular}

1. Career adaptability has a positive relationship with career management strategies

2. Conscientiousness, Cognitive flexibility and Environmental exploration are significant factors for career adaptability

3. Conscientiousness, Cognitive flexibility and Environmental exploration have an indirect relationship with career management strategies through career adaptability

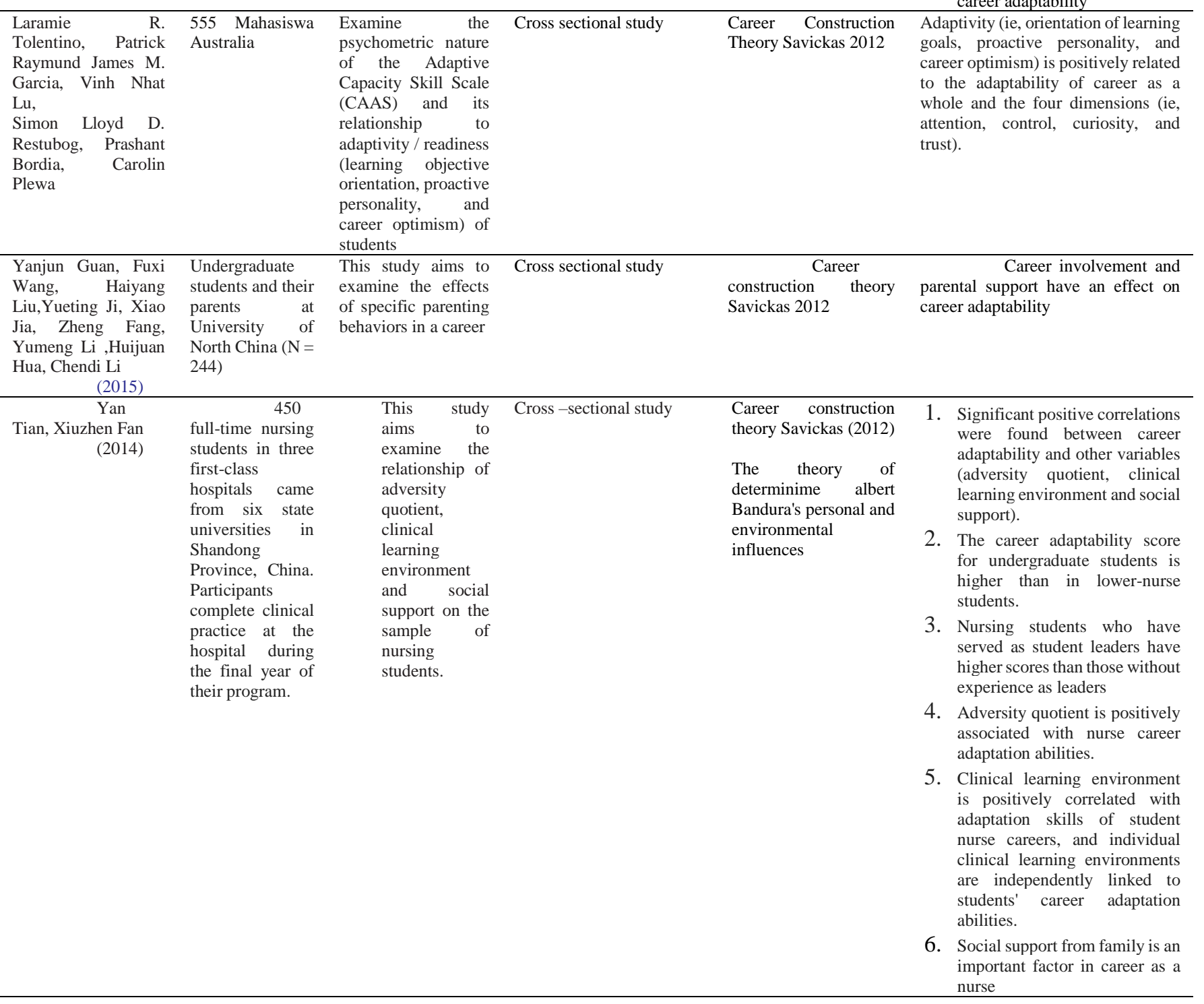

\section{RESULT}

The variables that are likely to cause career adaptability in the educational context in the various research results in this article are grouped based on the theory of career construction model (Savickas \& Porfeli, 2012) and based on personal and environmental factors that affect individuals.

\section{Demographic characteristics}

Based on research (Hirschi, 2009; Hirschi, 2010; Han \& Rojewski, 2015), who have examined the relationship between demographic characteristics with career adaptability in educational contexts. Demographic characteristics that are seen are age, gender, experience as class leader, education level of parents and associated with career adaptability. The results showed age did not correlate significantly with career adaptability levels(Hirschi, 2010).

Based on gender, men are more confident of higher abilities than women (Hirschi, 2009).Men are higher in career adaptability and experience career satisfaction than women (Han \& Rojewski, 2015). At the level of education, studies conducted on vocational education nurses in China obtained a score of career adaptability 
of upper level nurse studentswas reported higher than lower nurse students(Tian \& Fan, 2014). As for the level of education parents do not give effect to career adaptability(Hirschi, 2009).

\section{Adaptivity / career preparation / personality factors}

Researchers look at the personality factors associated with career adaptability dimensions, this is consistent with opinion(Savickas \& Porfeli, 2012). The results of the study linking the career adaptability with personality factors in the educational context were found in several studies (Hirschi, 2009; Wilkins et al., 2014).

The research findings indicate that positive emotional disposition, goal setting, goal orientation of learning (Hirschi, 2009; Negru-subtirica \& Pop, 2016; Tolentino et al., 2014); positive attitude of the future and future orientation (Cristina, Pallini, Maria, Nota, \& Soresi, 2016); hope (Wilkins et al., 2014); optimism (Negru-subtirica \& Pop, 2016; Tolentino et al., 2014; Wilkins et al., 2014); belief in ability skills is a significant predictor of career adaptability during a school year (Hirschi, 2009).

Conscientiousness, Cognitive flexibility (Chong \& Leong, 2017); adversity quotient (Tian \& Fan, 2014); proactive personality (Tolentino et al., 2014) the presence of meaning in life is a predictor of career adaptability for male and female students (Yuen \& Yau, 2015); Internal and external career barriers are found to be negatively related to the commitment of vocational identity through academic primary satisfaction, the effect is particularly prominent in the low level of career adaptability (Urbanaviciute, Pociute, Kairys, \& Liniauskaite, 2016)

\section{Social support}

The environmental factor of social support is found from the results of empirical studies. The support in question is support from parents, family, social environment, school, and friends related to career adaptability. The research results, social support(Hirschi, 2009; Tian \& Fan, 2014; (Han \& Rojewski, 2015), school support (Tian \& Fan, 2014; Han \& Rojewski, 2015).

\section{The success of career adaptability in education}

The success of career adaptability and the ineffectiveness of career adaptability affect education in individuals. The results found related to success in career adaptability are the sense of power (Hirschi, 2009); career management strategy (Chong \& Leong, 2017), academic satisfaction (Buyukgoze-kavas, Duffy, \& Douglass, 2015, Hirschi, 2009); life satisfaction(Santilli, Marcionetti, \& Nota, 2017) and academic achievement (which is Grand PointAcademic); academic fatigue, and academic involvement (Merino-tejedor, Hontangas, \& Boadagrau, 2016); perceived career obstacles(Hirschi, 2010); Self-regulation(Merino-tejedor et al., 2016).

\section{DISCUSSION}

Based on the model of career construction theory (Savickas \& Porfeli, 2012), which aims to examine the various results of empirical testing of career readiness, career success, demographic factors and environmental factors and career adaptability in the educational context hence obtained some findings.

Based on demographic data, age and gender related and career adaptability. Studies on students in Switzerland, age and gender do not affect the development of career adaptability. This result implies that for Swiss teenagers gender and age does not affect the development of career adaptability (Hirschi, 2009). However,the results of studies in Korea obtained different results, men expressed higher in career adaptability than women. This possibility is related to greater family responsibilities than women and the quality of support from the family (Han \& Rojewski, 2015). Based on the results of this study gender seems to be influenced by cultural factors. Swiss teenagers in grade 8 are required to determine an apprenticeship according to their wishes and interests regardless of gender.

At the level of education, studies conducted on vocational education nurses in China obtained a score of career adaptability of upper level of nurse students was reported higher than lower nurse students(Tian \& Fan, 2014). In addition, it was found that nursing students who had served as class leaders had higher scores than those without experience as leaders. This shows the greater the individual's knowledge of his career will support the development of individual career adaptability.Parental education does not affect the development of career adaptability (Hirschi, 2009). However, highly educated parents do not mean into better career preparation.

Based on career readiness or personality factors associated with career adaptability dimensions, the results of positive emotional disposition variable, goal setting, ability beliefs are significant predictors of career adaptability during 1 year of school (Hirschi, 2009); orientation of learning goals, optimism, proactive personality (Tolentino et al., 2014)

The research on students in Australia orientation of learning goals foundthat optimism has a correlation with the four-dimensional career adaptabilities(Tolentino et al., 2014). Research on future positive attitudes, similar research on expectations and optimism that are the dimensions of future positive attitudes have a correlation with career adaptability. The results of the study on Italian high school students, obtained the results of expectations have a significant relationship with all subcategories of career adaptability (concern, curiosity, confident and control). Optimism has correlation with 3 subcategories of career adaptability that is confidence, concern and control but has no correlation with curiosity(Wilkins et al., 2014). In the subjects of high school students, optimistic is not related to curiosity about career, however, the student optimism is one predictor of curiosity in one dimension of career adaptability.

Other findings related to personality factors are conscientiousness, cognitive flexibility and environmental exploration are significant factors for career adaptabilities(Chong \& Leong, 2017). Adversity quotient is positively associated with nurse career 
adaptation abilities(Tian \& Fan, 2014). Proactive personality (Tolentino et al., 2014)Self-regulation has a positive correlation with career adaptability (Merinotejedor et al., 2016).

Findings from a wide range of support both support from parents, social environment, school, and friends related to career adaptability. Research results, high social support is a strong predictor in career adaptability (Hirschi, 2009; Tian \& Fan, 2014; (Han \& Rojewski, 2015). School support, the support of clinical learning environments at nurses has a positive correlation between career adaptability sub scales(Tian \& Fan, 2014; Han \& Rojewski, 2015). High levels of parental support and low levels of parental intervention will affect career exploration which will predict career adaptability. Significant relationships are also found among the three types of parental behavior that is at a low level of career involvement, the positive effect of parental support and the negative effect on intervention behavior in the elderly with career exploration is strong. When parents are heavily involved in career development, it can lead to positive and negative effects, depending on the level of supportive behavior. A Social support from the family is an important factor in career as a nurse engagement behavior. For example, when parents are involved in career development and can provide supportive resources, students are more likely to initiate exploratory behavior; However, if parents engage in career development but cannot provide supportive resources, students tend to reduce their career exploration behavior(Guan et al., 2016). Social support from the family is an important factor in career as a nurse(Tian \& Fan, 2014; Han \& Rojewski, 2015).

The presence of meaning in life is a predictor of career, control, curiosity, and self-confidence in boys and girls. The search for meaning in life is not a predictor of a career for male students but it is the linkage of school that is a predictor of the career of male students. As for women searching meaning in life is not associated with caring or career confidence but for women career connectedness is a predictor of career awareness although career attention is predicted by the meaning in life and connectedness in school, but connectedness with peers is negative (Yuen \& Yau, 2015).

The success of career adaptability and the ineffectiveness of career adaptability affect education in individuals. Success in career adaptability can be either positive or negative. Success in career adaptability career adaptability affects sense of power(Hirschi, 2009); career management strategy (Chong \& Leong, 2017), academic satisfaction (Buyukgoze-kavas, Duffy, \& Douglass, 2015, Hirschi, 2009); life satisfaction(Santilli et al., 2017) and academic achievement (ie Grand Point Academic). This suggests that adolescents with a strong future orientation, investing in career planning activities tend to perform better in school and vice versa. The higher the academic achievement strengthens the teen's positive outlook on their future vocational, and gives positive relationship from academic achievement to career control and career confidence throughout one academic year (Negrusubtirica \& Pop, 2016).
Career adaptability has a negative correlation with academic fatigue, and academic involvement (Merinotejedor et al., 2016). Low career adaptability will lead to low academic satisfaction as well. Internal barriers such as the lack of potential and individual interest have a bearing on the commitment of vocational identity reinforced by academic satisfaction. Career adaptability does not moderate the direct relationship between perceived career barriers and vocational identity commitment (Hirschi, 2010)

\section{Limitations}

Based on the several literature studies that have been done, some researches are using cross sectional and longitudinal approach. The cross sectional approach has limitations that cannot show the causality(Negrusubtirica \& Pop, 2016; Wilkins et al., 2014). While in the longitudinal study declared the data obtained at the end of the session so that it cannot show the appropriate results (Hirschi, 2009).

The research report is a self-reporting act, which limits the validity of the research because the methodological variance in all constructs is assessed, and the use of convenience samples, which limit the generalization of results (Hirschi, 2009). The report itself allows biased results (Urbanaviciute et al., 2016).

Future research should take into social account and environmental factors such as parental support, resources provided by schools, or employment opportunities, and the models to gain a more comprehensive view of how individual environmental features and factors interact to influence career and management adaptability strategic career (Chong \& Leong, 2017). Many environmental factors are becoming the evidence as a predictor of career adaptability development, as well as in the context of education, campus, schools have an academic atmosphere, different campus climate influence of social support is still need to be developed.

In addition, the factors of career readiness that is personality factor in accordance with the concept of Savickas theory on career construction proved as a predictor of career adaptability. However, this factor is still being developed, such as linking career adaptability with coping behavior, self-esteem, self-efficacy; interest in career is possible to do research with these variables in order to expand the concept of career adaptability in educational context.

Some researchers have examined career adaptability associated with personal factors and demographic data, external factors such as parental influences and demographic data, but there are still a few studies that link internal and external factors in the career preparedness stage.

\section{CONCLUSION}

Based on the concept of career construction (Savickas \& Porfeli, 2012), researchers conducted a literature review of various research results both longitudinal and cross-sectional. Based on these studies it can be concluded that the factors that cause career adaptability are demographic factors, personality factors and social support. Demographic factors are gender, and experience as class leader. The factors of career 
readiness / personality factors are conscientiousness, negative emotional disposition, self-confidence, future orientation, hope, optimism, adversity quotient and self regulation. The external factors that affect career adaptability are the social support of parents, families, school environment. While the factors which can affect in career adaptability are life satisfaction, sense of power, career management, career certainty, class involvement, academic fatigue, and academic achievement.

\section{REFERENCE}

Arnett, J. J. (2003). Emerging Adulthood: Understanding the New Way of Coming of Age.

Buyukgoze-kavas, A. (2014). Validation of the Career Adapt-Abilities Scale-Turkish form and its relation to hope and optimism, 23(3), 125-132 https://doi.org/10.1177/1038416214531931.

Buyukgoze-kavas, A., Duffy, R. D., \& Douglass, R. P. (2015). Exploring links between career adaptability, work volition, and well-being among Turkish students. Journal of Vocational Behavior. 90 122-131. https://doi.org/10.1016/j.jvb.2015.08.006.

Chong, S., \& Leong, F. T. L. (2017). Antecedents of Career Adaptability in Strategic Career Management, 25(2), 268-280 https://doi.org/10.1177/1069072715621522.

Creed, P., Prideaux, L. A., \& Patton, W. (2005). Antecedents and consequences of career decisional states in adolescence. Journal of Vocational Behavior, 67(3), 397-412. https://doi.org/10.1016/j.jvb.2004.08.008

Cristina, M., Pallini, S., Maria, G., Nota, L., \& Soresi, S. (2016). Future orientation and attitudes mediate career adaptability and decidedness. Journal of Vocational Behavior, 95-96, 102-110. https://doi.org/10.1016/j.jvb.2016.08.003.

Green, B. N., Johnson, C. D., \& Adams, A. (2001) Writing narrative literature reviews for peerreviewed journals : secrets of the trade, 101-117.

Guan, P., Capezio, A., Lloyd, S., Restubog, D. Read, S., Ann, J., ... Li, M. (2016). The role of traditionality in the relationships among parental support, career decision-making self-ef fi cacy and career adaptability. Journal of Vocational Behavior 94,

114-123. https://doi.org/10.1016/j.jvb.2016.02.018.

Han, H., \& Rojewski, J. W. (2015). Gender-

Specific Models of Work-Bound Korean Adolescents ' Social Supports and Career Adaptability on Subsequent Job Satisfaction, 42(2), 149-164.

https://doi.org/10.1177/0894845314545786.

Hirschi, A. (2009). Career adaptability

development in adolescence: Multiple predictors and effect on sense of power and life satisfaction. Journal of Vocational Behavior, 74(2), 145-155. https://doi.org/10.1016/j.jvb.2009.01.002.

Hirschi, A. (2010). Swiss Adolescents' Career Aspirations : Influence of Context, Age, and Career Adaptability, 228-245. https://doi.org/10.1177/0894845309345844.

Hurtado, S., Han, J. C., Sa, V. B., Cabrera, N. L., \& Cerna, O. S. (2007). Predicting Transition And Adjustment To College: Biomedical And Behavioral Science Aspirants' And Minority Students', 48(7). https://doi.org/10.1007/s11162007-9051-x.
Kerr, S., Johnson, V. K., Gans, S. E., \& Krumrine, J. (2004). Predicting Adjustment During the Transition to College: Alexithymia, Perceived Stress, and Psychological Symptoms. Journal of College Student Development, 45(6), 593-611. https://doi.org/10.1353/csd.2004.0068.

Merino-tejedor, E., Hontangas, P. M., \& Boadagrau, J. (2016). Career adaptability and its relation to self-regulation , career construction , and academic engagement among Spanish university students. Journal of Vocational Behavior, 93, 92102. https://doi.org/10.1016/j.jvb.2016.01.005.

Negru-subtirica, O., \& Pop, E. I. (2016) Longitudinal links between career adaptability and academic achievement in adolescence. Journal of Vocational Behavior, 93(37), 163-170. https://doi.org/10.1016/j.jvb.2016.02.006.

Neuman, W. L. (n.d.). Social Research Methods: Qualitative and Quantitative Approaches.

Porfeli, E. J., \& Savickas, M. L. (2012). Career Adapt-Abilities Scale-USA Form: Psychometric properties and relation to vocational identity. Journal of Vocational Behavior, 80(3), 748-753. https://doi.org/10.1016/j.jvb.2012.01.009.

Santilli, S., Marcionetti, J., \& Nota, L. (2017). Career Adaptability, Hope, Optimism, and Life Satisfaction in Italian and Swiss Adolescents, 44(1), 62-76. https://doi.org/10.1177/0894845316633793.

Savickas, M. L. (2007). Career Adaptability: An Integrative Construct for Life-Span, $\mathrm{L}$ i fe-Space Theory, 45, 247-259.

Savickas, M. L., \& Porfeli, E. J. (2012). Career Adapt-Abilities Scale: Construction, reliability, and measurement equivalence across 13 countries. Journal of Vocational Behavior, 80(3), 661-673. https://doi.org/10.1016/j.jvb.2012.01.011.

Schwartz, S. J., Côté, J. E., \& Arnett, J. J. (2005). Youth \& Society. https://doi.org/10.1177/0044118X05275965.

Skorikov, V. (2007). Continuity in adolescent career preparation and its e $\mathrm{V}$ ects on adjustment $\mathrm{Q}$, 70, 8-24. https://doi.org/10.1016/j.jvb.2006.04.007.

Tian, Y., \& Fan, X. (2014). Adversity quotients , environmental variables and career adaptability in student nurses. Journal of Vocational Behavior, $85(3)$, 251-257. https://doi.org/10.1016/j.jvb.2014.07.006

Tolentino, L. R., Raymund, P., Garcia, J. M., Nhat, V., Lloyd, S., Restubog, D., ... Plewa, C. (2014). Career adaptation: The relation of adaptability to goal orientation , proactive personality , and career optimism is. Journal of Vocational Behavior, 84(1), 39-48. https://doi.org/10.1016/j.jvb.2013.11.004.

Urbanaviciute, I., Kairys, A., Pociute, B., \& Liniauskaite, A. (2014). Career adaptability in Lithuania : A test of psychometric properties and a theoretical model. Journal of Vocational Behavior, $85(3)$, 433-442. https://doi.org/10.1016/j.jvb.2014.09.005.

Urbanaviciute, I., Pociute, B., Kairys, A., \& Liniauskaite, A. (2016). Perceived career barriers and vocational outcomes among university undergraduates: Exploring mediation and moderation effects. Journal of Vocational Behavior, 92 https://doi.org/10.1016/j.jvb.2015.11.001.

Wilkins, K. G., Santilli, S., Ferrari, L., Nota, L., Tracey, T. J. G., \& Soresi, S. (2014). The relationship among positive emotional dispositions 
, career adaptability, and satisfaction in Italian high school students is. Journal of Vocational Behavior,

$85(3)$,

329-338.

https://doi.org/10.1016/j.jvb.2014.08.004.

Yuen, M., \& Yau, J. (2015). Relation of career adaptability to meaning in life and connectedness among adolescents in Hong Kong. Journal of Vocational Behavior, $91, \quad 147-156$. https://doi.org/10.1016/j.jvb.2015.10.003. 